Ankara Üniversitesi

SBF Dergisi,

Cilt 74, No. 1, 2019, s. 237 - 255

Araştırma Makalesi

\title{
A NEO-GRAMSGIAN ANALYSIS OF THE INCOMPLETE DOHA DEVELOPMENT TRADE ROUND *
}

\author{
Dr. Öğr. Üyesi Sevgi Balkan Şahin \\ Çağ Üniversitesi \\ Avrupa Birliği Araştırma ve Uygulama Merkezi \\ ORCID: 0000-0001-7227-4359
}

\begin{abstract}
This paper analyzes the lack of progress and the breakdown of the Doha Round talks in world trade since 2001 from a neo-Gramscian perspective. The failure to conclude multilateral trade negotiations reflect an emerging new architecture of power politics in the world political-economic order. Major economic powers, including the United States (US), the European Union (EU), Japan and Canada as well as leading transnational companies used to have a significant impact on guiding the agenda of the multilateral trade negotiations as well as defining the outcomes. However, in the context of the WTO, emerging powers such as India, Brazil, and China and several non-governmental organizations critical of neoliberal globalization began to confront the former groups' dominance. Developing and developed countries have contending views on the agenda issues, marked by confrontation on the former's insistence for the liberalization of agricultural markets by industrialized states and the latter's pressure for the liberalization of non-agricultural markets. Both sides employ certain strategies and discourses to coerce or to persuade the opposing parties. Hence, the paper argues that the multilateral trade negotiations emerge as zones of exercising hegemony rather than being an area to produce common norms, values and policies for the well-being of all members in the world trade regime.
\end{abstract}

Keywords: Hegemony, Counter-hegemony, Doha trade round, Emerging powers, NGOs

Tamamlanamayan Doha Kalkınma Ticaret Müzakerelerinin NeoGramşiyan Perspektiften Analizi

\section{Öz}

Bu çalışma 2001 yılından bu yana devam eden ve tamamlanamayan Doha Ticaret Müzakerelerini Neogramşiyan perspektifi çerçevesinde ele almaktadır. Çok taraflı ticaret görüşmelerinin sonuçsuz kalması, uluslararası politik-ekonomik düzende ortaya çıkan yeni bir güç siyaseti mimarisini yansıtmaktadır. Birleşik Devletler (ABD), Avrupa Birliği (AB), Japonya ve Kanada’nın yanı sıra önde gelen ulusötesi şirketler, çok taraflı ticaret müzakerelerinin gündemine rehberlik etme ve sonuçların tanımlanmasında önemli bir etkiye sahipken, Hindistan, Brezilya ve Çin gibi yükselen güçler ile neoliberal küreselleşmeyi eleştiren sivil toplum örgütleri bu grupların egemenliğine karşı koymaya başlamıştır. Bu iki grup, müzakere gündemine ilişkin birbiriyle çelişen görüşlere sahiptir. Gelişmekte olan ülkeler sanayileşmiş devletlerin tarım piyasalarının serbestleştirilmesini isterken, gelişmiş ülkeler ise tarım dışı pazarların liberalizasyonu için baskı yapmaktadır. Her iki taraf da kendi görüșünü çeșitli söylem ve stratejilerle karșı tarafa kabul ettirmeye çalıșmaktadır. Bu nedenle, çok taraflı ticaret görüşmeleri, dünya ticaret rejimindeki tüm üyelerin refahı için ortak normlar, değerler ve politikalar üretmek için bir alan olmaktan çok, gelişmiş ve gelişmekte olan ülkeler, çok uluslu şirketler ve sivil toplum örgütleri arasında hegemonya mücadelesini yansıtmaktadır.

Anahtar Sözcükler: Hegemonya, Karș1-hegemonya, Doha ticaret görüșmeleri, Yükselen güçler, Sivil toplum kuruluşları

* Makale geliş tarihi: 13.11 .2017

Makale kabul tarihi: 06.03.2018 


\section{A Neo-Gramscian Analysis of the Incomplete Doha Development Trade Round}

\section{Introduction}

With the creation of the World Trade Organization (WTO) in 1994, the multilateral trade regime has been drastically restructured and expanded. The new legal structure extended the mandate of the General Agreement on Tariffs and Trade (GATT) to areas as diverse as intellectual property rights, services, and investment. Developed countries that significantly benefitted from the new structure of the world trade called for further deepening and widening of world trade governance (Cohn, 2002:210-214). They proposed to launch a new trade round that would include new issue areas, including competition, trade facilitation, investment, and government procurement.

Considering capitalist international order as divided between dominant and less powerful countries that are exploited and controlled by the former, Fukuda (2010) defined this further attempt of broadening the scope of the world trade governance by developed countries as a policy of neo-imperialism. Neoimperialism may be defined as the extension of geo-economic and geo-political dominance of developed countries to institutionalize unequal power relations over other countries (Nkrumah, 1965). However, this paper highlighted how the attempt of furthering the neoliberal transformation of the trade regime by powerful countries has been challenged by a coalition of developing countries and civil society actors that accordingly lad to an impasse in the recent trade talks of the WTO. It emphasized how the clash of ideas over the future agenda of the WTO drove various social forces into a continuous struggle of ideas, discourses and power relations.

Due to the dissatisfaction from the Uruguay Round agreements, developing countries and non-governmental organizations (NGOs) that successfully leveraged the mounting discontent among developing countries started to voice their concerns on the future of world trade and called for a balanced restructuring of the system. In order to respond to the concerns of developing countries and NGOs that promoted a positive association between trade and development, the latest trade round initiated in November 2001 was named as the Doha Development Round. Since the start of the negotiations, talks 
have failed over a confrontation on several issues, including agriculture, export subsidies, non-agricultural market access (NAMA), services, and trade facilitation. For instance, the resistance of developing countries and several NGOs against the inclusion of new issues such as competition and investment to the multilateral trade regime negotiations led to the collapse of the Cancun Ministerial Conference in 2003.

Negotiations were revived with the 2004 Framework Agreement; however, the talks stumbled once again in the Hong Kong ministerial conference held in 2005. After the suspension of the negotiations at the General Council Meeting in Geneva in July 2006, and later in July 2008, several attempts were made to revive the Doha Round. These attempts also ended in failure and little substantive progress has been made since then. Even the latest ministerial conference that brokered a deal on contentious issues such as agricultural subsidies and export competition in Nairobi in 2015 failed to overcome the overall deadlock in Doha Round negotiations. The $11^{\text {th }}$ Ministerial conference scheduled to be held in Buones Aires in December 2017 does not offer any prospect of successfully concluding the round, either.

This paper applies a neo-Gramscian approach to explore the dynamics of the failure of the further transformation of the multilateral trade regime through the Doha Development Round. It analyzes the failure of regime transformation by focusing on the changes that took place in broader historical structures. As will be elaborated in more detail in the following section, from a neo-Gramscian perspective, changes in the material basis and ideational framework of historical structures and world orders affected the process of the creation and transformation of international regimes. Accordingly, this paper considers WTO multilateral negotiations not only as an instrument of international law making but as an ongoing hegemonic struggle of social forces, their material interests and ideas in a changing world economy and global order.

\section{The Neo-Gramscian Approach in International Relations}

Based upon an intersubjective ontology and historicist epistemology, the Neo-Gramscian approach examines the emergence and evolution of international regimes, institutions, and social power-relations as embedded in certain historical structures (Cox, 1981: 89). According to this perspective, historical structures reflect the reciprocal interaction between material capabilities, ideas and institutions through which social forces shape the ideological framework of the world order and associated international regimes (Overbeek, 2004: 118; Bieler 
and Morton, 2001:212). Paying particular attention to the role played by social forces as the most important collective actors in the regime change, it analyzes how market actors produce policy formulas and promote them to the states through the creation of a dominant global discourse on the requirements of the world economy (Baker, 1999; Overbeek, 2005). It also examines how social forces attempt to generate consent for their policy proposals by disseminating their ideas, values, and worldview as serving the general interests of all actors, although they may only benefit the particular needs of market actors (Deckwirth, 2007).

The neo-Gramscian perspective analyzes this consent manufacturing process of market actors through the concept of hegemony. According to Gramsci (1971:160-161), hegemony reflects the acceptance of the values, norms, and expectations of the ruling groups by the subordinate as common or general interests. Hegemony reflects the process in which market oriented social forces use their moral and intellectual leadership to establish broad alliances required to generate active consent of the society (Gramsci 1971: 119-20; 238-9). Gramsci emphasizes the importance of organic intellectuals who can disseminate and legitimize hegemonic ideas of dominant social forces as a coherent world view for establishing alliances between various social groups (Gramsci 1971:330). For Gramsci, building hegemony is thus a long-run process that entails the incorporation of different interests and expectations under a broad alliance to create consensus among wider society (Bieler and Morton, 2003:479; Bieler, 2006:123).

Gramsci (1971) argues that because of the possibility of the emergence of opposition to the hegemonic system, hegemony is not a once and for all process. Those sections of society that refuse to give their consent and instead challenge the legitimacy of dominant groups lead to the emergence of counter-hegemonic movements. Therefore, from a neo-Gramscian perspective, to sustain the operation of hegemony, hegemonic ideas such as the virtue of markets should be complemented with legal or administrative enforcement (Gill, 1996:216). Moreover, international institutions that strengthen market economy with binding rules and protect market from popular scrutiny or democratic accountability are seen as necessary for the expansion of hegemonic world order and the absorption of counter-hegemonic challenges (Gill, 1992:165).

Based upon these insights, it can be argued that the attempt of further deepening the WTO with new rules through the Doha Round reflects an attempt of transnational social forces to lock in new market disciplines on states. Nevertheless, as will be explained below, the failure of the Doha negotiations illustrates the limits to their power of further transforming the trade regime as the emergence of new economic powers such as India, China, and Brazil together 
with the contestation of neoliberal hegemony, institutions and policies by a large set of civil society actors created a new context for trade agendas.

\section{Changing Historical Structure, Social Forces, and the WTO after the Uruguay Round}

The liberalization of financial markets after the end of the Bretton Woods system of fixed exchange rates were coupled with the revival of neoliberal economic ideas that imposed market norms and disciplines over the states (Helleiner, 1994; Baker, 1999). This material and ideological shift brought about transformation not only in the world order, including changes in political power configurations, but also in the intersubjective frameworks of international regimes. With its broad mandate in areas such as intellectual property rights, services, and investment, the WTO deepened global market integration by further opening up new market opportunities in formerly protected areas. Thus, the WTO can be seen as characterizing the institutionalization of new neoliberal disciplinary measures codifying the reconfiguration of the world order (Altay, 2011:334).

Benefiting from the neoliberal world order, transnational corporations (TNCs) in developed countries continued to pressure their respective governments in terms of further strengthening the rules in international trade in such areas as competition, investment, trade facilitation, and government procurement, the so-called Singapore issues (Deutsch, 2001:35-36). In neoGramscian terms, the hegemonic social forces in the world trade regime were determined to strengthen their domination and their advantages through inclusion of new rules into the regime. Scholte et al (2001: 118) state that 65 percent of the civic organizations accredited to attend the first ministerial conference that convened in Singapore in 1996 represented business interests. Smith and Moran (1999:68 cited in Kapoor, 2004:530) also indicate that 'More than five hundred corporation and business representatives were given official credentials as 'trade advisors' to the US delegation in Seattle'.

In WTO gatherings, TNCs of developed countries promoted Singapore issues as bringing economic benefits for all countries. They strategically argued that implementation of stronger rules concerning the government procurement, competition, investment, and trade facilitation process would fasten the transnational economic activities, and that, in turn, would directly contribute to the well-being of economies of developed and developing countries (Boyd, 2002: 97-100). The developing countries, on the other hand, had a different vision concerning the future of negotiations at the WTO. Although developing countries 
themselves gradually adopted neoliberal reforms and gave their consent for the creation of the WTO with a broader mandate, they were concerned about the implementation of the WTO package adopted in the Uruguay Round (Finger \& Schuler, 2001:117-118). Especially, implementing the TRIPS Agreement that transformed the patent and health care systems in line with market principles and the TRIMS Agreement that aimed at abolishing domestic restrictions in front of foreign investment turned out to be disadvantageous for their national economies (May, 2002:98-101; Gallagher, 2007:72). As a result, developing countries called to action against the increased burden of the implementation of the Uruguay Round and called for development-oriented revisions in the Uruguay Round agreements (Narlikar, 2003:213-214).

Several NGOs emerging as significant actors of influencing the agenda of the WTO and the position of the governments, responded to the plea of developing countries by defending the formulation of development-friendly trade rules that would respect labor concerns, environment, and sustainable development. With such demands, NGOs challenged the credibility and legitimacy of the WTO at the Seattle Ministerial Conference in 1999. Faced with the NGO' Seattle challenge and the new power configuration of developing countries, WTO members agreed to launch the Doha Development Round as a compromise between development concerns and further market access in areas, including investment, government procurement, and investment.

\section{The Initial Phase of Doha Round Negotiations}

In the Doha Ministerial Conference, a large group of developing countries campaigned for the relaxation of the TRIPs rules in the areas concerning public health and they succeeded to change the key provisions of the TRIPs Agreement at the end of the Doha Round. In their success to revise the existing provisions of the TRIPs Agreement, the key thing was the ability of developing countries to introduce a new knowledge based discourse that linked public health and TRIPs Agreement with each other. As a result, in response to the discourse on the relationship between trade and intellectual property rights of hegemonic social forces, developing countries framed a counter discourse through claiming the connection between intellectual property rights and public health (Moon, 2010).

On reforming the existing rules in TRIPs Agreement during the Doha Ministerial Conference, African Group, composed of forty-one countries, took the leadership role in bargaining with the developed countries, particularly the United States (US). Zimbabwe, the leader of the African Group, called for the right to access to medicines and the relaxation of the TRIPs rules (Mutlu, 
2008:102). The call from the African Group facilitated the expansion of the group into sixty members that included Brazil and India that later on took the leadership role. The shared idea on the right to access medicines sustained the coherence within the group. The presence of valuable pharmaceutical industries in Brazil and India provided opportunity to engage in technical work, and the group succeeded to produce detailed and validly grounded proposals (Odell \& Sell, 2006: 98-99). In other words, the shared common sense on access to medicines produced a consensus. Developing countries succeeded to carry this discourse on public health to the mass media in industrialized countries. This directly contributed to the activism of NGOs and civil society organizations (Sell \& Prakash, 2004:146-149). Consequently, an alliance was built between developing countries and developed country NGOs based on the shared idea on the linkage between intellectual property rights and public health. The strategy of building a broader alliance in their resistance to the hegemony of transnational capital in the realm of TRIPs Agreement and public health tilted the balance towards developing countries in the Doha Ministerial Conference (Moon, 2010).

Although developing countries were able to relax the TRIPs agreement with regard to public health issues, the key interests of developing countries on agriculture, textile and implementation related problems could not be brought into a feasible solution. Indeed, the key development related concerns of developing countries were not taken into account by the developed countries during Doha Round negotiations. Despite the strong resistance of the developing countries, it was agreed that the Singapore Issues would be an integral part of the new round of multilateral trade negotiations. Raising a strong opposition against the Singapore issues, African Group and G-77 called for the removal of market access barriers, export subsidies, and domestic support in agriculture. Primarily concerned with the export subsidies used by the European Union (EU) and Japan, developing countries argued that those subsidies totally distort trade in agriculture and push agricultural sector into crisis in the developing world (Panagariya, 2002:1209).

Developing country negotiators insisted that although the EU had made reforms in its Common Agricultural Policy (CAP), these reforms were still far from removing protectionist measures. They criticized that the direct export subsidies just shifted to the subsidies for rural development and food safety (Anderson, 2001:32-34). On the other hand, the EU and Japan rejected the immediate removal of export subsidies, and they just called for a feasible time table to reform their agricultural sectors. Moreover, the EU Trade Commissioner stated that if developing countries want concessions in agriculture, they should offer something in environment and Singapore issues (Kwa \& Jawara, 2004:105). This uncompromising attitude of both parties led to the recurrent 
suspension and revival of the negotiations for more than fifteen years without a final solution.

\section{Reframing Power Relations and the Battle at the Cancun Ministerial Conference}

The WTO Ministerial Conference held in Cancun, Mexico, 2003 showed that the dominant forces in global economy, such as the US, EU, Canada and Japan (the so-called Quad) no longer had the monopoly position of exerting influence over the agenda of multilateral trade negotiations. With their greater role in the world economy as leading producers and exporters in key sectors ranging from information technology to chemicals, from pharmaceuticals to environmental goods, Brazil, India, and China altered the balance of economic power as well as levels of economic integration (Schwab, 2011). This new power configuration in the world order significantly had an impact on the Doha negotiations.

Brazil, India, South Africa, and China led the G-20 which emerged as an issue based coalition centrally focused on the negotiations in agriculture, but at the same time it had a hybrid structure in its membership. For instance, Nigeria as a member of the G-20 was also a member of the African Caribbean Group (ACP), a block coalition of less developed countries of Africa and the Caribbean (Narlikar and Tussie, 2004: 952-955). Some G-20 countries also had overlapping membership with the Coalition on Strategic Products and Special Safeguard Mechanism (SSM) which struggled for national flexibility for defining the items to be considered as special products and identifying special treatment for them.

The combination of these coalitions such as ACP, African Group, Strategic Products Group and the G-20 was the G-90. The major advantage of multiple memberships among these coalitions was that developing countries were able to build inter-group dialogue, and they supported each other during the negotiations of different issues. Thus, they were able to reach a compromise among each other and they succeeded in adopting a coherent stance on a common ground besides their diverging sometimes conflicting interests (Narlikar and Wilkinson, 2004:457).

The G-20 objected further market opening in new areas and demanded a more equitable international order and a better access to the EU and US markets for agricultural products. Developing countries collectively mobilized their resources in terms of preparing proposals and formulating alternative policies, and engaged in hard bargaining with their developed counterparts. However, 
increasing activism of developing countries failed to produce expected outcomes due to the weak commitment on the part of developed countries.

Despite the pressure of developing countries to remove export subsidies immediately, the US Congress put in force new domestic subsidies through the 2002 Farm Bill. The introduction of the Farm Bill changed the interests in the US towards a more protectionist approach and the US cooperated with the EU in the discussions on agriculture. They jointly proposed an extended period for the removal of export subsidies. The joint proposal of the US and the EU on agriculture attracted major objections by the developing countries, and India and Brazil prepared a counterproposal that urged for the need to liberalize agriculture. They at the same time underlined the necessity to take necessary measures for net-food importing countries of developing world (Narlikar and Tussie, 2004:456-458).

The proposal took the support of the coalition of G-20. The presence of India and Brazil as the co-leaders of the group further contributed to the wellfunctioning of the group. With significant amount of technical and human capital, these two countries played the catalyst role in enhancing communication within the group and supplying information and technical assistance in the process of proposal making (Hurrell and Narlikar, 2006:422-425). Despite the agriculture's different levels of importance in their national economies, the members of the G20 succeeded to overcome their self-interested calculations and established a counter discourse and strategy against the proposals of the US and the EU.

In the broader debate over agriculture, four African countries (Chad, Mali, Burkina Faso, and Benin) made a plea for the immediate elimination of agricultural subsidies given by developed countries (Narlikar and Wilkinson, 2004:456-7). The cotton sector constituted more than half of the economic activity in those countries, and they were the major exporters of world cotton. In this respect, the support mechanisms of the US, the second major exporter of cotton, provided to the cotton producers caused decline in world cotton prices while the protectionist measures applied to the cotton imports prevented these African countries to enter into the US market (Anderson and Valenzuela, 2007). As a result of those negative measures, the level of poverty as well as hunger increased dramatically in these four countries, and they called for urgent action in re-balancing the world trade in cotton.

During the Cancun Ministerial, developing countries announced their dissatisfaction due to the lack of clarity concerning the negotiations in agriculture and overemphasis on Singapore issues (Wilkinson, 2004: 151). With the beginning of formal negotiations on Singapore issues, the African Group and LDC Group strongly opposed to the inclusion of those issues into the Development Round's agenda. In response to their demands, the EU, South 
Korea, Singapore, and Japan strongly demanded that they will not sit at the negotiation table unless there had been progress in the negotiations on Singapore issues (Baldwin, 2006). As a result, as will be analyzed in the case of the investment issue, the hegemonic struggle among opposing social forces led to the collapse of negotiations at the Cancun Conference.

\section{The Hegemonic Struggle of Social Forces over the Investment Issue in the Doha Round Negotiations}

After the failure of the OECD (Organization for Economic Cooperation and Development) initiative to create a Multilateral Agreement on Investment (MAI) in 1998, developed countries directed investment issues to the WTO agenda to ensure transparency, protection, and nondiscriminatory liberalization (Altay, 2011:246). By establishing a positive and complementary link between trade and foreign direct investment (FDI), developed countries tried to get the consent of developing countries for including the investment issue to the agenda of the Doha Trade Round. In their reports, they promoted FDI as bringing about technology transfer, knowhow, innovation, and a stimulus for exports while discrediting interventionist measures such as technology transfer requirements as distorting investment patterns (OECD, 1998; WTO, 1998a; 1998b).

A coalition of developing countries led by India resisted the inclusion of investment rules to the WTO agenda by arguing that countries should be flexible in designing their own investment policies to attract and direct FDI to selected industries or regions on the basis of their individual needs (Altay, 2011:255). Given the lack of a consensus on the investment issue, coupled with the tension in agriculture, developing countries, including China, India, Malaysia, Nigeria, and Bangladesh rejected negotiations in Singapore issues (Altay, 2011:315). They made it clear that unless progress was recorded in agriculture, the Southern alliances were unwilling to concede on these issues. The position of these developing countries was strengthened with the rise of the NGOs as one of the most influential actors contesting the inclusion of the investment issue to the WTO agenda.

Disillusioned by the negative consequences of the neoliberal globalization process, civil society actors mobilized against the institutionalization of selfregulating markets by the IMF, World Bank and the WTO (Gill, 2000; Morton, 2003; Morton, 2007; Bieler, 2008). Structural adjustment programs and neoliberal principles promoted by these institutions were argued to distort distribution of income and the level and pace of economic development. In early 
1997, as part of their campaign against the MAI, a group of NGOs led by Friends of the Earth, Public Citizen, and the Third World Network tried to discredit the MAI agreement as leading to the exploitation of labor and environment by capital groups (Tieleman, 2004:11).

The WTO was also criticized for its opaque decision-making that prioritized capital interests at the expense of environmental, social, and health concerns. The rise of the NGOs expanded the zones of discussion with regard to the governance of world trade since many of those organizations brought new issues such as labor rights and environmental protection into the agenda of the WTO (Schott, 2000:11-13). In their letter sent to Pascal Lamy, the EU Trade Commissioner, in May 2001, a pan- European network composed of 99 NGOs from several European countries accused the WTO for prioritizing the interests of TNCs while ignoring ordinary citizens and for taking decisions behind closed doors (Altay, 2011). They also asked for the cancellation of the new trade round that included contentious issues like competition and investment (Altay, 2011:307).

By promoting negative outcomes of an investment treaty, NGOs such as Oxfam International, the Center for International Environmental Law, Friends of the Earth, the International Institute for Sustainable Development, and the Institute for Agriculture and Trade Policy tried to decouple the positive link between investment and economic development (Murphy, 2012:476). By contesting the neoliberal arrangements, these actors served as counter-hegemonic forces that prevented the regulation of investment issues as part of the WTO (Altay, 2011:350). They promoted their critical ideas by contacting the negotiators in international gatherings in Geneva and by establishing websites such as Investment Watch (Murphy, 2007:11-2). They organized several workshops, published research papers, funded electronic newsletters on foreign investment issues in order to help developing countries to improve their negotiating strategies on the investment issue. In a joint conference organized by a network of more than 50 NGOs in March 2003 in Geneva, they adopted the declaration titled "No Investment Negotiations at the WTO: Declaration of Nongovernmental Groups and Civil Society Movements' (Murphy, 2012:477). Moreover, representatives of several NGOs participated to the Cancun ministerial conference as part of the official governmental delegation of developing countries including India, Nepal, Bangladesh, and some African countries (Murphy, 2012:477-478).

Under the pressure of NGOs, developed countries and capital groups began to readjust their strategies and failed to establish a strong coalition on the investment issue as they did during the Uruguay Round negotiations (Altay, 2011:349). Despite the strong support of the European business for the 
investment case, the US counterparts called for leaving investment out of the WTO talks. The US government accordingly proposed the withdrawal of competition and investment from the WTO agenda (Altay, 2011:315). While the EU agreed on removing competition and investment from the round talks, South Korea and Japan insisted that the talks be opened in all four issue areas (Altay, 2011:316). On the other hand, the fierce opposition of India and the African Union against four topics made it impossible to achieve a consensus, leading to the failure of the Cancun Ministerial conference.

\section{The Changing Power Structure and Stalled Negotiations at the Doha Round}

After the failure in Cancun, talks were resumed with the July 2004 Framework known as the July Package. Member states agreed to a framework on agriculture and non-agricultural market access (NAMA), and a commitment to keep talking about the extension of services and the TRIPs. Agreement was also reached on the contentious Singapore Issues, in which negotiators agreed to drop investment, competition and government procurement from the agenda (WTO, 2004). The launching of the July 2004 Framework after the collapse in Cancun was the beginning of a new term in the balance of power within the WTO. It was not the usual Quad countries (U.S., EU, Japan, and Canada) that negotiated the July Package. Recognizing the importance of India and Brazil as leaders of the G20, the July Package included the Five Interested Parties (FIP), comprising the US, the EU, Australia, India, and Brazil (Das, 2006:309-313).

Many of the informal negotiations were among these five countries; and Australia, Brazil and India were obliged to report back to their coalitions about the progress in meetings. In other words, these three countries attended the informal meetings as the representatives of their coalitions: Australia in the name of the Cairns Group, Brazil in the name of the G-20 and the ACP, and India for the G-20. The changing dynamics of power in the WTO to the advantage of developing countries was a major achievement for developing countries. Therefore, developing countries' unity and coherence can be regarded as the most important attempt of developing countries in challenging developed country domination of the WTO.

Despite the concessions given to developing countries, the July 2004 Package failed to motivate WTO members to further narrow differences in their substantive positions (Cho, 2010: 579). The $\mathrm{G}_{10}{ }^{1}$ representing the largest

1 Belgium, Canada, France, Italy, Japan, the Netherlands, the United Kingdom, the United States, Germany and Sweden 
agricultural exporting countries and the EU worried about the language in the July Package that called for severe reductions in domestic agricultural support. With the deepening of fractions among member states, the talks drifted back into a stalemate which generated a lot of pressure for the upcoming Ministerial conference scheduled for Hong Kong in 2005.

The Hong Kong Ministerial set a deadline for concluding the round by the end of 2006. However, the struggle among the EU, Brazil, and India over agricultural trade liberalization casted a shadow on achieving this target. The EU took a hardline negotiating position until the last minute of the Conference in order to get more concessions in agriculture as well as in other areas, especially in the issues of non-agricultural market access and services liberalization (Oxfam, 2005). Towards the end of the Conference, some progress was achieved as the EU accepted 2013 as the deadline for eliminating all sorts of export subsidies in agriculture as well as committed that the exports of least developed countries (LDCs) enjoy duty and quota-free access by 2008 (Cho, 2010: 579). However, there was no clear date for the elimination of domestic support that constituted the largest part in developed countries' subsidies on agriculture (Elliot, 2006:132-134).

In the Non-Agricultural Market Access negotiations, developed countries proposed lowering average tariffs by at least 30 percent, which would reduce the average developing country tariff from 12.5 percent to 5.9 percent for existing tariff lines (Gallagher, 2007:74). Developed countries pushed developing countries also to open up their services markets, especially in the financial and telecommunications sectors in places like Brazil and India in exchange for market access in agriculture (Gallagher, 2007:77-79). Developing nations were not necessarily opposed to this proposal but they argued for the insertion of an emergency safeguard mechanism (ESM) into GATS and proposed liberalizing employment services that would allow for more visas for professional employees (such as software engineers from India) and temporary visas for low-skilled workers (Gallagher, 2007:81). Developed countries rejected these proposals. Due to the lack of a consensus on contentious issues such as agricultural subsidies and industrial tariffs, the WTO General Council suspended the negotiations on 28 July 2006.

After the 2006 suspension of talks, various country groups attempted to restart negotiations. Key players, such as the G-4 (the US, the EU, Brazil and India) met bilaterally and in groups to break the impasse. By April 2007, the G6 (G4 plus Australia and Japan) agreed to push hard for ending the round by the end of the year. However, a G-4 summit in Germany during July 2007 ended in failure over the uncompromising position of developed and developing countries in reducing their subsidies and industrial tariffs, respectively. The Geneva 
Ministerial Meeting in 2008 and 2009 also ended without any substantial progress. In November 2010, Pascal Lamy called on countries to conclude Doha by the end of 2011. Despite this call, given little political will among leading members to make the serious compromises necessary to bring the round to a close, this deadline was missed.

The Bali package adopted in the Bali Ministerial conference held in December 2013 raised expectations about the conclusion of the round as it included measures on trade facilitation such as the liberalization of customs procedures and interim solutions on food security. Further progres was achieved in the 11th Ministerial Conference held in Nairobi in 2015 when member states finally agreed on longstanding issues such as agricultural subsidies and export competition through the so-called Nairobi package. Offering solutions in crucial areas such as market access, domestic support, export subsidies, special safeguard mechanism (SSM), food security, and preferential rules of origin, the Package was announced to create a level playing field in global trade in agriculture (WTO, 2015). Concerning the issue of export competition, the Export Competition Declaration of the Nairobi package required developed countries to eliminate their export subsidies immediately but enabled developing countries to terminate their subsidies by the end of 2018. With the Cotton Declaration, developed and developing country were required to grant duty-free and quota-free market access for cotton and cotton-related itemsproduced and exported by LDCs as of January 2016 (Martin and Mercurio, 2017:54). Moreover, the Package enabled less developed countries to have preferential access to the markets of devloped countries in the area of services until 31 December 2030.

However, examining the operational details of other issues in more detail, it is seen that the Nairobi package could not provide final solutions to some controversial issue arreas. For instance, based on the SSM adopted in the Hong Kong ministerial conference in 2005, developing countries had the right to temporarily increase agricultural tariff rates to alleviate problems such as trade distortions or price fluctuations due to import surges. However, in the Nairobi conference member states failed to determine which factors would necessiate the SSM or which tariff level would be sufficient to protect domestic agricultural market and farmers without undermining their commitments under the WTO rules (Martin and Mercurio, 2017:52). Moreover, while the Nairobi package recognized the importance of food security by allowing developing countries to buy food stocks at regulated prices, it failed to deliver a final solution on this issue as many countries opposed food security measures for their potential for dual use as disguised subsidies. As developed and developing countries could not compromise on their conflicting positions on crucial agenda items, there appears 
to be no end in sight for the Doha Round to be held in Buenos Aires in December 2017.

\section{Conclusion}

This paper examined the failure of the regime transformation of the WTO through Doha Round negotiations as a function of material and ideational changes within a broader historical structure. The paper has argued that the rise of new social forces and emerging economies that emphasize environmental, social, and political consequences of neoliberal commitments are crucial to understand why the latest trade round of the WTO failed to be concluded after more than a decade of intense negotiations. By examining why certain social forces encouraged the further transformation of the multilateral trade regime and why others opposed such transformation, this paper has addressed the issue of the role of agency in regime transformation. It has emphasized that the negotiations are conducted through inter-subjective interaction of social forces, thus the discourse they employ during the negotiations constitute the basis of power dynamics at the WTO. The paper thus tried to understand how the economic and political interests of social forces are turned into certain discourses in multilateral trade negotiations, and how a certain position of a country or group prevailed over the others.

To demonstrate the hegemonic struggle of social forces, the paper examined how market-oriented capital groups with vested interests in global production and finance networks tried to expand neo-liberal market rules and practices in WTO. It also analyzed how several NGOs have challenged attempts of furthering the WTO agenda with new neoliberal rules. For instance, capital groups promoted investment by emphasizing how FDI flows to developing countries would improve their level of economic development and welfare. However, this discourse failed to produce the necessary consensus during the Doha negotiations. Emerging powers and a network of NGOs attempted to deconstruct and delegitimize the arguments on the positive benefits of new investment rules on developing countries. Their counter-arguments led to the failure of Doha negotiations.

Based on this resistance, the paper has showed how emerging powers and NGOs challenged global trade regime that produced benefits for developed countries and capital groups but inequalities for developing countries at large. By emphasizing the unequal nature of world trading regime, the opponents tried to delegitimize the WTO and TNCs as representing capital interests at the expense of ordinary citizens and the nature. Moreover, with the growing power of emerging countries such as Brazil, China, and India, the exclusive club of G-7 
had lost its dominant position in world economy. Faced with the challenge coming from global civil society actors and emerging powers, capital groups and developed countries failed to maintain their unity on trade strategies and lost their capacity to produce consent for their vision of deepening world trade regime. This contested nature of neoliberal order was a significant factor in the failure of the Doha trade round. The WTO members have so far failed to produce any sort of compromising agenda that allowed movement towards completing the Doha Agenda.

\section{References}

Altay, S. (2011), "Hegemony, Private Actors, and International Institutions: Transnational Corporations as the Agents of Transformation of the Trade Regime from GATT to the WTO", Unpublished PhD Thesis, Trento University, Italy.

Anderson, Kym. (2001), "Bringing Discipline to Agricultural Policy via the WTO", in Hoekman, Bernard and Will Martin (eds.), Developing Countries and the WTO A Proactive Agenda (Oxford: Blackwell Publishers): 25-58.

Anderson, Kym and Ernesto Valenzuela (2007), "The World Trade Organization's Doha Cotton Initiative: A Tale of Two Issues", The World Economy, 30(8): 1281-1304.

Baker, Andrew (1999), "Nebuleuse and the Internationalisation of the State in the UK?", Review of International Political Economy, 6(1): 79-100.

Bieler, Andreas (2006), "Class Struggle over the EU Model of Capitalism: Neo-Gramscian Perspectives and the Analysis of European Integration", in Bieler, Andreas and A. David Morton (eds.), Images of Gramsci.Connections and Contentions in Political Theory and International Relations (New York:Routledge): 119-132.

Bieler, Andreas (2008), "The Deficits of Discourse in IPE: Turning Base Metal into Gold?", International Studies Quarterly, 52:103-128.

Bieler, Andreas and A. David Morton (2001) Social Forces in the Making of the New Europe: The Restructuring of European Social Relations in the Global Political Economy (London: Palgrave)

Bieler, Andreas and A. David Morton (2003), "Globalization, the State and Class Struggle", British Journal of Politics and International Relations, 5(4):467-499.

Boyd, Gavin (2002), "Triad Policy and Interdependencies in the WTO", in Rugman, Alan M. and Gavin Boyd (eds.), The World Trade Organization in the New Global Economy Trade and Investment Issues in the Millennium Round (Cheltenham and Northampton: Edward Elgar): 95-127.

Cho, Sungjoon (2010), "The Demise of Development in the Doha Round Negotiations", Texas International Law Journal, 31: 573-601. 
Cohn, Theodore H. (2002), Governing Global Trade: International Institutions in Conflict and Convergence (Hampshire: Ashgate).

Cox, Robert W. (1981), "Social Forces, States and World Orders", Millennium: Journal of International Studies, 10(2): 126-55.

Das, Dilip (2006), "The Doha Round of Multilateral Negotiations and the Embellishing Role of the Developing Economies", The International Trade Journal, 20(3): 307-354.

Deckwirth, Christina (2007), "Compromises and failures in the GATS negotiations. The impact of the WTO-services agreement on the evolvement of international standards in the services sector", Paper presented at the Sixth Pan-European International Relations Conference, 12-15 September, Turin, Italy.

Deutsch, Klaus Giinter (2001), "The EU: Contending for Leadership”, in Deutsch, Klaus Giinter and Bernhard Speyer (eds.), The World Trade Organization Millennium Round. Freer Trade in the Twenty First Century (London: Routledge): 34-47.

Elliott, Kimberly Ann (2006), "Agricultural Reform and Trade Negotiations Can the Doha Round Deliver?", World Economics, 7(4): 125-145.

Finger, Michael and Philip Schuler (2001), "Implementation of Uruguay Round Commitments: The Development Challenge", in Hoekman, Bernhard and Will Martin (eds.) Developing Countries and the WTO A Pro-active Agenda (Oxford: Blackwell Publishers): 115-130.

Fukuda, Yasuo (2010), "WTO Regime as a New Stage of Imperialism: Decaying Capitalism and its Alternative", World Review of Political Economy, January.

Gallagher, Kevin P. (2007), "Understanding developing country resistance to the Doha Round", Review of International Political Economy, 15(1): 62-85.

Gill, Stephen (1992), "The Emerging World Order and European Change: the Political Economy of European Union", in Leys, Colin and Leo Panitch (eds.), The Socialist Register (London: Merlin).

Gill, Stephen (1996), "Globalization, Democratization and the Politics of Indifference" in Mittelman, James H. (ed.), Globalization: Critical Reflections (London: Lynne Reinner).

Gill, Stephen (2000), "Toward a Postmodern Prince? The Battle in Seattle as a Moment in the New Politics of Globalization", Millennium: Journal of International Studies, 29(1): 131-40.

Gramsci, Antonio (1971), Selections from the Prison Notebooks of Antonio Gramsci (London: Lawrence and Wishart).

Helleiner, Eric (1994), States and the Reemergence of Global Finance: From Bretton Woods to the 1990 s (Ithaca: Cornell University Press).

Hurrell, Andrew and Amrita Narlikar (2006) "A New Politics of Confrontation? Brazil and India in Multilateral Trade Negotiations", Global Society, 20 (4): 415-433.

Kapoor, Ilan (2004), "Deliberative democracy and the WTO", Review of International Political Economy, 11(3): 522-541.

Kwa, Aileen and Fatoumata Jawara (2004), Behind the Scenes at the WTO: the Real World of International Trade Negotiations - Lessons from Cancun (London:Zed Books).

Martin, Antoine and Bryan Mercurio (2017), "Doha dead and buried in Nairobi: lessons for the WTO", Journal of International Trade Law and Policy, 16(1):49-66.

May, Christopher. (2002), A Global Political Economy of Intellectual Property Rights: The New Enclosures (London: Routledge).

Moon, Suerie (2010), 'Embedding Neoliberalism: Global Health and the Evolution of the Global Intellectual Property Regime', Unpublished PhD Thesis, Harvard University. 
Morton, Adam David (2003), "Structural Change and Neoliberalism in Mexico: 'Passive Revolution' in Global Political Economy", Third World Quarterly, 24 (4): 631-653.

Morton, Adam David (2007), Unravelling Gramsci: Hegemony and Passive Revolution in the Global Political Economy (London:Pluto Press).

Murphy, Hannah (2007), "NGOs, Agenda-Setting and the WTO", Refereed paper presented at the Australasian Political Studies Association Conference, Monash University, 24-26 September.

Murphy, Hannah (2012), "Rethinking the Roles of Non-Governmental Organizations at the World Trade Organization", Australian Journal of International Affairs, 66 (4): 468-485.

Mutlu, K. (2008), "World Trade: Power Politics, Discourses, and Existing Asymmetries in the WTO", Masters Thesis, Koc University, İstanbul.

Narlikar, Amrita (2003), International Trade and Developing Countries: Bargaining Coalitions in the GATT \& WTO, London: Routledge.

Narlikar, Amrita and Rorden Wilkinson (2004), "Collapse at the WTO: a Cancun post-mortem", Third World Quarterly, 25(3): 447-460.

Narlikar, Amrita and Diana Tussie (2004), "The G-20 at Cancun Ministerial: Developing Countries and Their Evolving Coalitions in the WTO", World Economy, 27(7): 947-966.

Nkrumah, Kwame (1965) Neo-Colonialism: The Last Stage of Imperialism (London: Thomas Nelson \& Sons).

Odell, John S. and Susan K. Sell (2006), "Reframing the Issue: the WTO Coalition on Intellectual Property and Public Health, 2001", in Odell, John S. (ed.), Negotiating Trade: Developing Countries in the WTO and NAFTA (Cambridge: Cambridge University Press): 85-114.

OECD (1998), "Foreign Direct Investment and Economic Development", Document No. WT/WGTI/W/26, 23 March.

Overbeek, Henk (2004), "Transnational Class Formation and Concepts of Control: Towards a Genealogy of the Amsterdam Project in International Political Economy", Journal of International Relations and Development, 7(2): 113-141.

Overbeek, Henk (2005), "Globalization, Neo-liberalism and the Employment Question" in Overbeek Henk (ed.), The Political Economy of European Employment: European Integration and the Transnationalization Question (New York: Routledge): 13-29.

Oxfam (2005), "What Happened in Hong Kong: Initial Analysis of the WTO Ministerial, December 2005", Oxfam Briefing Paper, no. 85. http://www.oxfam.org/en/policy/briefingpapers/ bp85_hongkong (15.01.2016).

Panagariya, Arvind (2002), "Developing Countries at Doha: A Political Economy Analysis", The World Economy, 25(9): 1205-1233.

Schwab, Susan C. (2011), "After Doha”, Foreign Affairs, 90(3): 104-117.

Scholte, Jan Art, O'Brien, Robert and Williams, Mark (1999), "The WTO and Civil Society", Journal of World Trade, 33(1): 107-23.

Sell, Susan K. and Aseem Prakash (2004), "Using Ideas Strategically: The Consent Between Businesses and NGOs in Intellectual Property", International Studies Quarterly, 48(1): 143176.

Schott, Jeffrey J. (2000), "The WTO after Seattle', in Schott, Jeffrey J. (ed.) The WTO After Seattle (Washington: Institute for International Economics): 3-40.

Smith, Jackie and Moran, Timothy (2000), "WTO 101: Myths about the World Trade Organisation", Dissent, 2: 66-70. 
Tieleman, Katia (2004), "The Failure of the Multilateral Agreement on Investment (MAI) and the Absence of A Global Public Policy Network", Case Study for the UN Vision Project on Global Public Policy Networks, www.globalpublicpolicy.net (23.05.2016).

Wilkinson, Rorden (2004), "Global Insights Crisis in Cancun”, Global Governance, 10: 149-155.

WTO (1998a), Synthesis of the Information Made Available to the Working Group on the Links Between Foreign Direct Investment and Development Note by the Secretariat,Document No.WT/WGTI/W/38, 5 June.

WTO (1998b), The Effects of Foreign Direct Investment on Development: Technology and Other Know-How Transfers and Spillovers - Note by the Secretariat, Document No. WT/WGTI/W/65, 20 November.

WTO (2004), Doha Work Program: Decision Adopted by the General Council on 1 August 2004, Document No. WT/L/579, 2 August.

WTO (2015), WTO members scrutinize agriculture support measures of major traders, News ItemsAgriculture: Formal Meeting, 25 September, https://goo.gl/27tPfA (12.10.2016). 